Ethiopian Journal of Environmental Studies \& Management 9(4): 508 - 522, 2016.

ISSN:1998-0507

doi: http://dx.doi.org/10.4314/ejesm.v9i4.10

Submitted: April 26, 2016

Accepted: August 02, 2016

\title{
ASSESSMENT OF GROUNDWATER QUALITY IN RURAL AREAS OF MBALA DISTRICT, ZAMBIA
}

\author{
*NYIRENDA, K., ${ }^{1}$ CHEELO, G. ${ }^{2}$ NGULUBE, R. ${ }^{1}$ AND MVULA, M. ${ }^{3}$ \\ ${ }^{1}$ Copperbelt University, School of Mines and Mineral Sciences, P O Box 21692, Kitwe, \\ Zambia \\ ${ }^{2}$ Mulonga Water and Sewerage, P O Box 11712, Chingola, Zambia \\ ${ }^{3}$ World Vision Zambia, P O Box 31083, Lusaka, Zambia
}

\begin{abstract}
Access to good quality drinking water still remains a challenge in most rural areas of Zambia, Africa. The aim of this study was to assess the quality of groundwater for human consumption in rural areas of Mbala district in Zambia. A total of fifty nine (59) water samples were collected from fifty nine (59) boreholes in the aforementioned district. The water samples were analysed for physical, chemical and microbiological parameters using standard techniques specific for each parameter. Results were compared to the Zambian Bureau of Standards (ZABS) guideline values for drinking water and in some cases, with WHO guideline values if known. In general, most water parameters in Mbala district complied with ZABS drinking water guideline values. A few chemical parameters which include $\mathrm{pH}$ ranging from 5.1 to 6.98 , sodium from $0.001 \mathrm{mg} / \mathrm{L}$ to $49.9 \mathrm{mg} / \mathrm{L}$, sulphate from $2 \mathrm{mg} / \mathrm{L}$ to $18.76 \mathrm{mg} / \mathrm{L}$, iron from 0 to $10.22 \mathrm{mg} / \mathrm{L}$ and manganese from 0 to $0.23 \mathrm{mg} / \mathrm{L}$ did not meet $Z A B S$ drinking water guideline values at a few boreholes. TSS and turbidity ranged from 0 to $133 \mathrm{mg} / \mathrm{L}$ and 2 to 358NTU respectively. A few exceedances of the aforementioned parameters were recorded at a few boreholes. In contrast, significantly high turbidity levels (>20NTU) were recorded at a few boreholes in the district thus posing a significant threat to the health of the consumers. In terms of microbiological parameters, a few boreholes did not meet the ZABS drinking water guideline values for total coliforms rendering the water supplies from the affected boreholes unfit for human consumption unless boiled or treated with chlorine.
\end{abstract}

Key Words: Groundwater, Zambia, rural areas, water quality, Mbala district

\section{Introduction}

In most rural and peri-urban areas of Zambia, groundwater is the main source of water for drinking and other domestic uses (IWMI, 2012). Mbala district in Northern Province of Zambia is no exception as most rural communities in

*Corresponding Author: Nyirenda, K.

Email: nyirendakenny@gmail.com the district rely on groundwater from furrows and hand dug wells (Bury, 1998). In most cases, these water sources are unprotected which puts them under threat of contamination from anthropogenic inputs. 
Although Zambia is endowed with abundant water resources, the majority of the population lack access to good quality drinking water especially in rural communities (IGRAC, 2013). This prompted the Zambian government and its co-operating partners to embark on a countrywide improvement and increasing of access to clean and safe drinking water especially in rural communities. African Development Bank, World Bank and World Vision Zambia are some of the organisations supplementing the government's efforts in the provision of clean and safe drinking water through proper siting and drilling of standard boreholes in rural communities.

It should be noted that although the majority of people in rural communities of Zambia depend on groundwater, there is paucity of information on groundwater quality in the country (ADB, 2013; Norrgren et. al., 2000). With limited chemical data on chemical composition of groundwater resources in Zambia, there is need for urgent research in the country to assess the drinking water quality of the available groundwater resources (BGS, 2001; IWMI, 2012; World Bank, 2009). Limited available chemical data however suggest that the Zambian groundwater has generally very low concentrations of dissolved constituents (ADB, 2013; MacDonald, 1990)

According to the Geological Survey of Sweden (2014), the Zambian Department of Water Affairs which is responsible for the overall management of water resources in the country has up until recently mainly focussed on water quantity and not quality. In terms of water quality, the department is less strong in its performance and lack both the capacity and knowledge to survey the major water resources especially groundwater (GSS, 2014; IMWI, 2012). Moreover, groundwater resources in Zambia are less well understood than surface water despite the importance of the resource in social and economic development of the country (UOG, 2010). Against this background, the objective of this study was to assess the quality of groundwater for human consumption in rural areas of Mbala district in Northern Province of Zambia.

\section{Site Location and Description}

Mbala district is located in Northern Province of Zambia. It is $1067 \mathrm{Km}$ from Lusaka, the capital city of Zambia and shares an international border with Tanzania. The district lies between $9.1570^{\circ} \mathrm{S}$ and $31.5370^{\circ} \mathrm{E}$, and is mostly mountainous with numerous rivers and seasonal streams (Bury, 1998). Mbala has access to two lakes namely lake Chila and Tanganyika. As of the year 2010, the district population was estimated at 213,254 (GEOHIVE, 2015). According to UNICEF (2002), more than $70 \%$ of the district population falls in the low socioeconomic status with women being the most affected. Farming in Mbala district is the main source of income and livelihood for the local communities. The district is also rich in precious and semiprecious minerals and has great potential for tourism. 


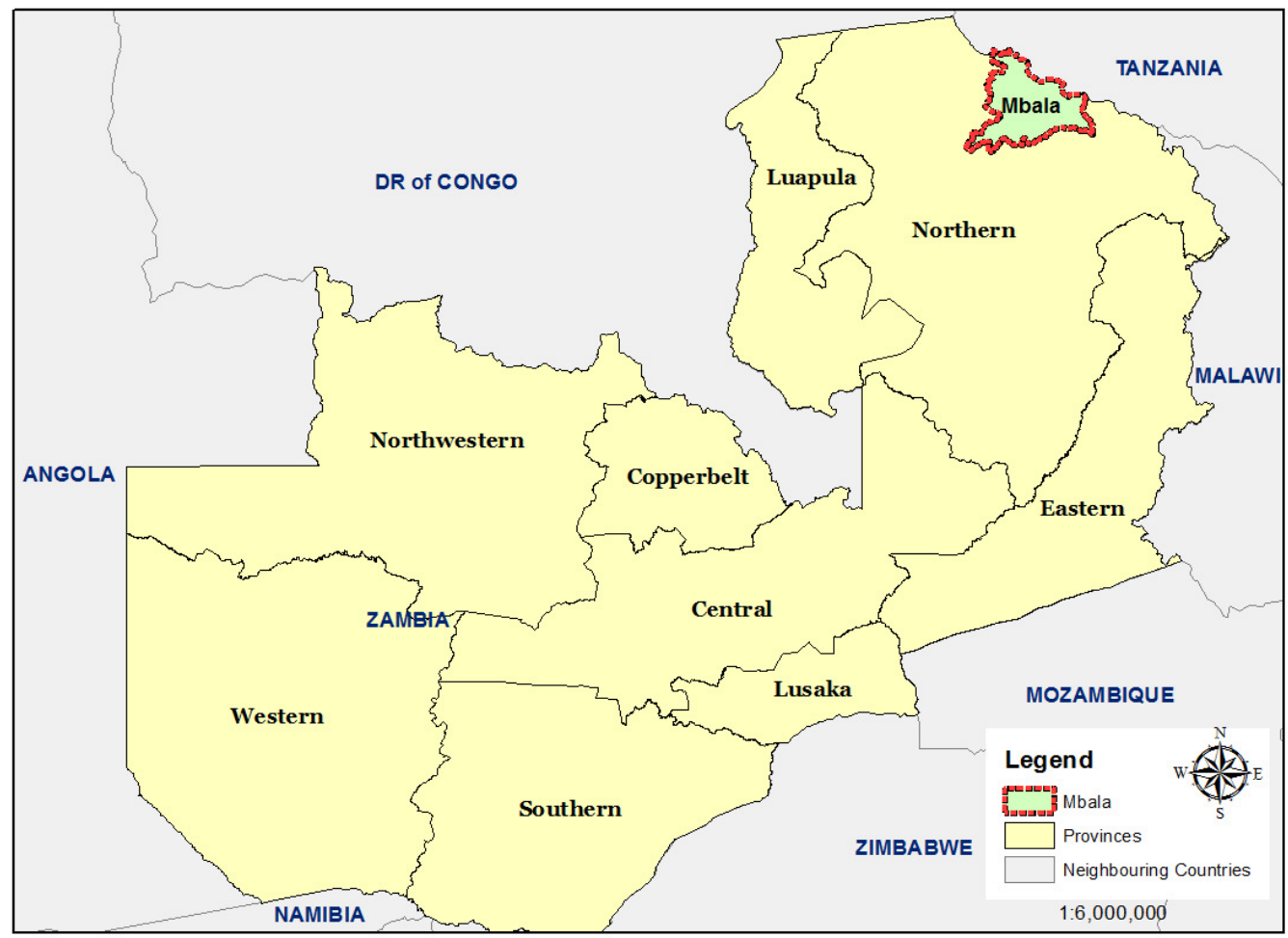

Figure1: Map showing the location of the study area

\section{Geology and Hydrogeology of the Study Area}

Most parts of Northern Province of Zambia where the study area lies are underlain by the rocks of the Basement Complex including granites, metaigneous and meta-volcanic rocks (JICA, 1995; SRK, 2002). In some parts of the Province, the Basement Complex is unconformably overlain by sedimentary rocks of the Katangan Supergroup. Borehole logging from the drilling programme carried out by World Vision Zambia shows that most areas in Mbala district are underlain by granites from the Basement Complex. However, in some areas, the granites are overlain by the sediments (feldspar rich sandstones) from the Katangan Supergroup.

The Basement Complex forms the major aquifer units in Northern Province of Zambia. According to JICA (1995), groundwater in the Basement Complex rocks occur within joints, faults and weathered zones. The report further states that fracture zones in the Basement Complex rocks usually extend to depths of between 30 to $40 \mathrm{~m}$ and in some cases up to $90 \mathrm{~m}$. The weathered Basement Complex rocks form the shallow aquifer system in the Province. The fractured and weathered Basement Complex aquifers in Northern Province are categorized as locally productive as shown below (Figure 2). In certain areas of Northern Province, low yielding aquifers with limited potential are known to occur within meta-igneous and meta-volcanic units of the older Basement Complex (JICA, 1995). 


\section{Assessment of Groundwater Quality in Rural Areas of Mbala.................NYIRENDA et al.}

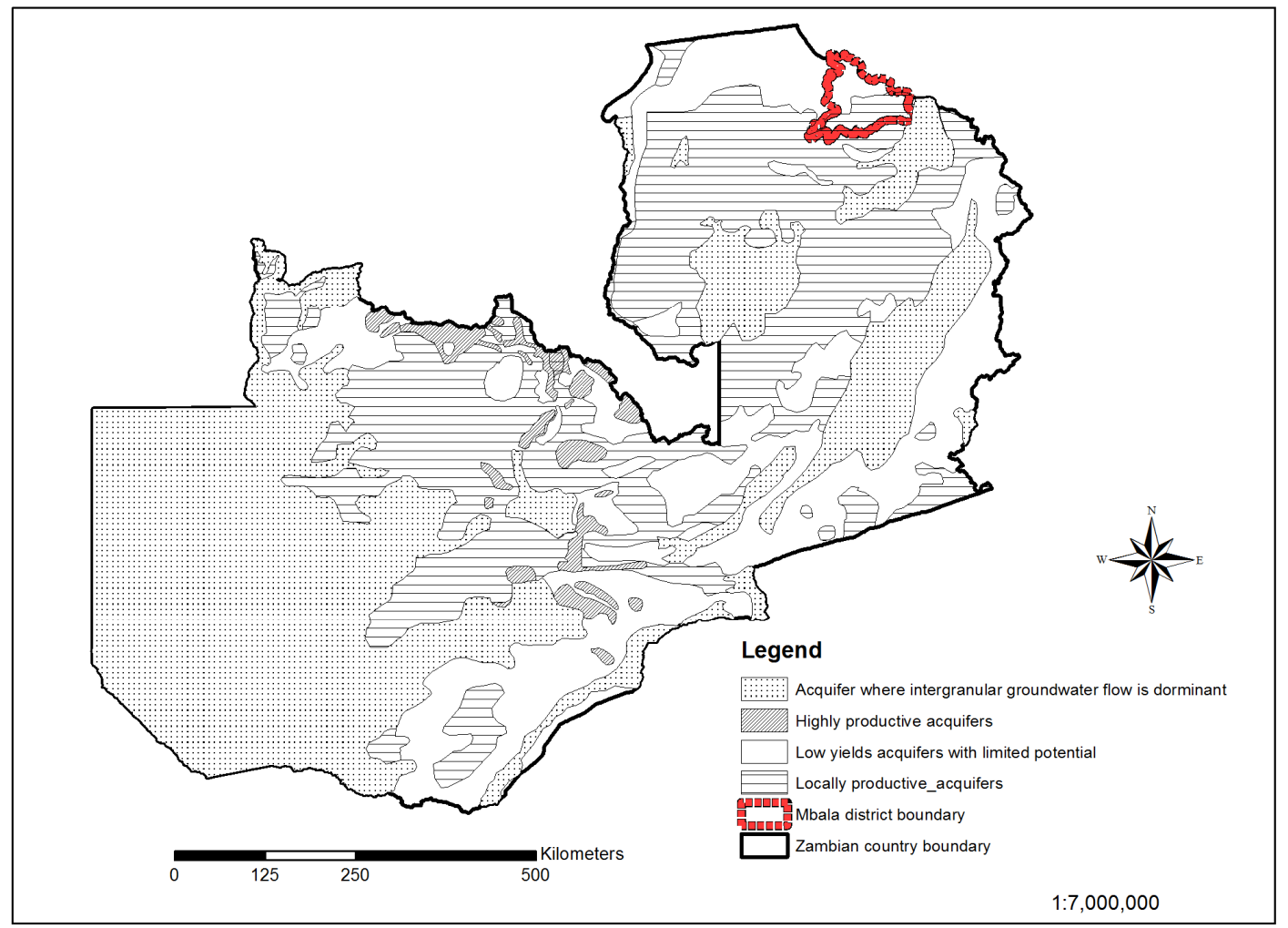

Figure 2: Map of Zambia showing the Distribution of the Aquifer Units (modified after JICA, 1995)

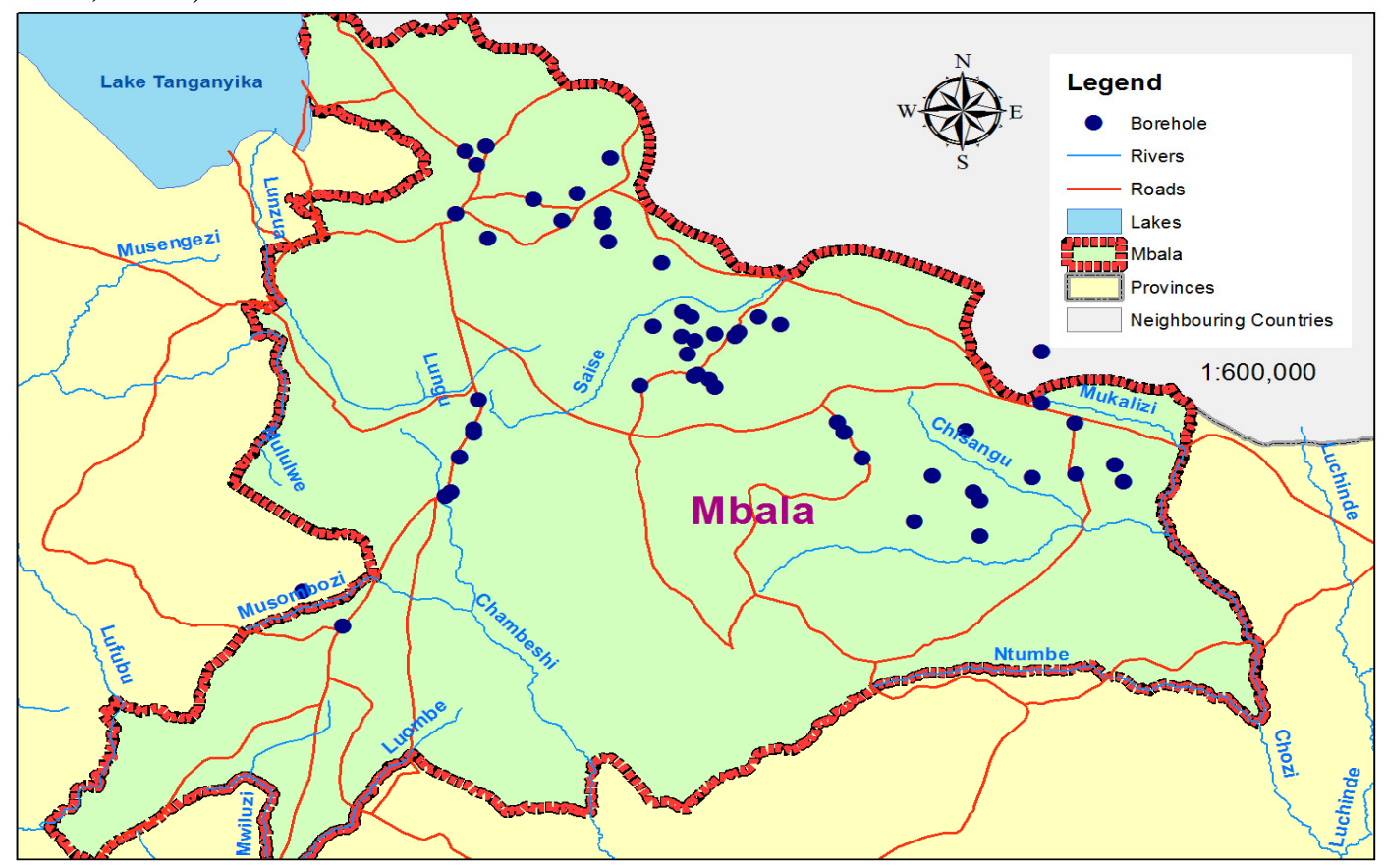

Figure 3: Map showing the distribution of boreholes in the study area 


\section{Methodology}

\section{Sample Collection Framework, Handling and Preservation}

A total of 59 borehole water samples were collected from October, 2013 to September, 2014 from boreholes drilled by World Vision Zambia. Borehole water samples were collected after conducting a pumping test for about 4 to 6 hours to ensure that the water is visibly clear and clean. After the pumping test, one litre of water sample from each borehole was collected in a cleansed polythene bottle after 20 minutes of continuous pumping. At least 5 to 15 samples were collected from boreholes in a day. In each water bottle, some space was left in order to prolong the life of microbiological organisms.

Once the borehole water samples were collected, they were immediately placed in a cool box and transported by road to the laboratory within 24 to 48 hours. For sample preservation, ice blocks were put in cool boxes during transportation to keep them cool as the laboratory was situated about $1000 \mathrm{~km}$ from the site.

\section{Laboratory Sample Analysis}

The collected borehole samples were immediately analysed for physical, microbiological and chemical parameters at the Environmental laboratory under the Copperbelt University in Zambia. pH measurements were done with a Hanna pH 213 microprocessor $\mathrm{pH}$ meter and electrical conductivity (EC) was measured using an Accumet AP75 electrical conductivity meter. Nitrates were analysed using the calorimetric cadmium reduction method (AWWA, 1995) and the test for the presence of total and faecal coliforms were done using membrane filtration method (UNEP/WHO, 1996). Turbidity was measured using the nephelometer or turbidimeter (AWWA, 1995). In general, all water samples were analysed using standard technique specific for each parameter (AWWA, 1995; UNEP/WHO, 1996).

\section{Data Analysis}

To assess the drinking water quality, various physical, chemical and microbiological parameters were compared to their permissible value(s) set by the Zambia Bureau of Standards (ZABS) for drinking water (Table 1 and 2 ) and in some cases to World Health Organisation guideline values if known. 
Table 1: Zambia Bureau of Standards Permissible Levels and World Health Organisation Guideline Values for Parameters of Concern in this Study

\begin{tabular}{lll}
\hline Parameter & $\begin{array}{l}\text { ZABS Permissible } \\
\text { Value }\end{array}$ & $\begin{array}{l}\text { WHO (2008) Drinking } \\
\text { Water Guide Values }\end{array}$ \\
\hline EC & $1500 \mu \mathrm{S} / \mathrm{cm}$ & Not stated \\
TDS & $800 \mathrm{mg} / \mathrm{l}$ & No stated \\
Hardness & $250 \mathrm{mg} / 1$ & Not stated \\
TSS & $100 \mathrm{mg} / \mathrm{l}$ & Not stated \\
Turbidity & $5 \mathrm{NTU}$ & Not stated \\
$\mathrm{pH}$ & $6.5-8.0$ & Not stated \\
Alkalinity & $500 \mathrm{mg} / 1$ & Not stated \\
Nitrates & $10 \mathrm{mg} / \mathrm{l}$ & $50 \mathrm{mg} / 1$ \\
$\mathrm{Mn}$ & $0.1 \mathrm{mg} / \mathrm{l}$ & $0.4 \mathrm{mg} / \mathrm{l}$ \\
Fe & $0.3 \mathrm{mg} / \mathrm{l}$ & Not stated \\
Ca & $100 \mathrm{mg} / 1$ & Not stated \\
Mg & $250 \mathrm{mg} / 1$ & Not stated \\
Na & $1.5 \mathrm{mg} / 1$ & Not stated \\
Fluorine & $1.0 \mathrm{mg} / 1$ & $1.5 \mathrm{mg} / 1$ \\
Chlorine & $250 \mathrm{mg} / 1$ & Not stated \\
Phosphate & $0.1 \mathrm{mg} / \mathrm{l}$ & Not stated \\
Sulphate & $1 \mathrm{mg} / \mathrm{l}$ & Not stated \\
Total Coliform & $0 \mathrm{tc} / 100 \mathrm{ml}$ & Not stated \\
Faecal Coliform & $0 \mathrm{cfu} / 100 \mathrm{ml}$ & Not stated \\
\hline
\end{tabular}

Table 2 below shows the summary of physical and chemical parameters for the 59 borehole water samples analysed from various villages in Mbala district. For each physical and chemical parameter, the minimum, maximum and average values were determined coupled with the percentage of boreholes that did not comply with the ZABS permissible values for drinking water. In terms of microbiological parameters, only $22 \%$ of the borehole water samples tested positive for total coliforms. 
Table 2: Summary of Physical and Chemical Data on Groundwater Quality in Mbala District

\begin{tabular}{llllll}
\hline Parameter & Min & Max & Average & $\begin{array}{l}\text { ZABS } \\
\text { Permissible Value } \\
(\mathrm{PV})\end{array}$ & $\begin{array}{l}\text { Percentage of Water } \\
\text { Samples not in } \\
\text { compliance with the PV }\end{array}$ \\
\hline EC & 43 & 511 & 132.62 & $1500(\mu \mathrm{S} / \mathrm{cm})$ & 0 \\
TSS & 0 & 133 & 41.35 & $100 \mathrm{mg} / \mathrm{L}$ & 17 \\
TDS & 0.001 & 358 & 70.28 & $8000 \mathrm{mg} / \mathrm{L}$ & 0 \\
Turbidity & 2 & 358 & 19.71 & $5 \mathrm{NTU}$ & 49.1 \\
Hardness & 0.001 & 330 & 28.54 & $250 \mathrm{mg} / \mathrm{L}$ & 0 \\
pH & 5.1 & 6.98 & 6.3 & $6.5-8.0$ & 47.5 \\
Alkalinity & 0 & 312 & 29.9 & $500 \mathrm{mg} / \mathrm{L}$ & 0 \\
Ca & 0.001 & 41.6 & 6.21 & $100 \mathrm{mg} / \mathrm{L}$ & 0 \\
Mg & 0 & 57.2 & 3.69 & $250 \mathrm{mg} / \mathrm{L}$ & 0 \\
Cl & 1 & 43.99 & 14.26 & $250 \mathrm{mg} / \mathrm{L}$ & 0 \\
Fl & 0 & 0.16 & 0.02 & $1 \mathrm{mg} / \mathrm{L}$ & 0 \\
Fe & 0 & 10.22 & 0.49 & $0.3 \mathrm{mg} / \mathrm{L}$ & 22 \\
Sulphate & 2 & 18.76 & 2 & $1 \mathrm{mg} / \mathrm{L}$ & 37 \\
Nitrate & 0 & 3.98 & 0.09 & $10 \mathrm{mg} / \mathrm{L}$ & 0 \\
Phosphate & 0 & 0.6 & 0.03 & $1 \mathrm{mg} / \mathrm{L}$ & 5 \\
Mn & 0 & 0.23 & 0.04 & $0.1 \mathrm{mg} / \mathrm{L}$ & 14 \\
\hline
\end{tabular}

\section{Results and Discussion}

The results of various water parameters analysed from the collected water samples in various villages in Mbala district as tabulated in Table 2 above. A total of fifty nine (59) borehole water samples were analysed for nineteen (19) parameters as shown in Table 1 and 2.

Physical Characteristics of Analysed Borehole Water Samples

Physical parameters for the borehole water samples are presented in Tables 2 and 3. The values for electrical conductivity (EC) and total dissolved solids (TDS) complied with the Zambia Bureau of Standards (ZABS) drinking water guideline values except for turbidity and total suspended solids.

Turbidity values in borehole water samples ranged from $2 \mathrm{NTU}$ to $358 \mathrm{NTU}$ with about $49 \%$ of these samples recording turbidity levels greater than ZABS drinking water guideline value of
5NTU. High turbidity levels ( $>5$ NTU) recorded in some borehole water samples could be attributed the improper selection of the borehole screens or damaged casing pipes. The aforementioned factors can allow fine particles to enter the borehole during pumping. Furthermore, the nature of the underlying aquifer may also contribute to high turbidity levels in some boreholes. During flushing period, it was observed that groundwater in areas where the aquifer is highly fractured and less competent sandstone formation took longer to become visibly clear and clean than in areas underlain by the crystalline basement aquifer (granite). Fine particles from the fractured sandstone aquifer may easily be drawn to the borehole especially during high pumping rates. According to World Health Organisation (2008), high turbidity levels can seriously interfere with the disinfection process of the water 
as the particulate matter tend to protect the pathogens.

Total suspended solids (TSS) recorded in borehole water samples in this study ranged from 0 to $266 \mathrm{mg} / \mathrm{l}$. However, the majority (about 84\%) of the borehole water samples recorded the levels of total suspended solids (TSS) less than the permissible limit of $100 \mathrm{mg} / \mathrm{l}$ set by the ZABS for drinking water. A few borehole water samples (about 16\%) slightly exceed the TSS maximum permissible value of $100 \mathrm{mg} / \mathrm{l}$ set by ZABS. This could also be attributed to the damaged casing pipes or improper selection of borehole screens by the drilling contractor. High levels of total suspended solids in drinking water can also have profound effects on human health as they tend to inhibit pathogens and other toxic chemicals.

\section{Chemical Characteristics of Borehole Water Samples}

Results of all the analysed chemical parameters from the collected borehole water samples in Mbala district are presented in Tables 2 and 4. From these results, almost all borehole water samples recorded concentrations of nitrate, phosphate, hardness, alkalinity, fluorine, chlorine, magnesium and calcium complied with the Zambia Bureau of Standards guideline values for drinking water with the exception of sodium, iron, manganese, sulphate and $\mathrm{pH}$.

The $\mathrm{pH}$ of the borehole water samples were slightly acid and ranged from 5.1 to 6.98. About $48 \%$ of water samples did not comply with ZABS permissible $\mathrm{pH}$ range of 6.5-8.0 for drinking water. According to Giovanoli (et al., 1988), the hydrolysis of feldspars from granitic rocks produces silicic acid which may affect the $\mathrm{pH}$ of groundwater. Therefore, the weak acidic nature of groundwater in Mbala district could be attributed to the weathering of feldspars from the granite and sandstone formations which makeup the major aquifers units in the area. Although the $\mathrm{pH}$ of groundwater in Mbala district is slightly acid, it has no direct health effects to the consumers. It is however advisable to treat slightly acidic water $(\mathrm{pH}<6)$ with hydrated lime to ensure that the $\mathrm{pH}$ falls within the permissible range for drinking water.

Concentrations of manganese from the majority (about $86 \%$ ) of the borehole water samples complied with ZABS permissible value of $0.1 \mathrm{mg} / \mathrm{l}$ of manganese in drinking water. However, about $14 \%$ of the borehole water samples recorded manganese levels slightly greater than the permissible value of $0.1 \mathrm{mg} / \mathrm{l}$. It should be noted that concentrations of manganese recorded from borehole water samples ranged from $0.0 \mathrm{mg} / 1$ to $0.23 \mathrm{mg} / \mathrm{l}$. This concentration range is within the expected range of $\mathrm{Mn}$ $(0.01 \mathrm{mg} / \mathrm{l}$ to slightly greater than $10 \mathrm{mg} / \mathrm{l})$ in natural waters free from anthropogenic inputs (WRA, 2013). Concentrations of manganese in all the borehole water samples complied with WHO health guideline value of $0.4 \mathrm{mg} / \mathrm{l}$ hence will not likely affect the health of the consumers. However, water supplies from a few boreholes which exceeded manganese concentration of $0.1 \mathrm{mg} / 1$ will likely impart undesirable taste to drinking water.

Iron concentrations in borehole water samples ranged from 0 to $10.22 \mathrm{mg} / \mathrm{l}$. The majority (about $78 \%$ ) of water samples complied with ZABS permissible value of $0.3 \mathrm{mg} / \mathrm{l}$ for drinking water. Only a few water samples (about 22\%) slightly exceeded ZABS permissible value of 
$0.3 \mathrm{mg} / \mathrm{l}$ of iron in drinking water. According USEPA (2015), excessive amounts of iron are known to occur in many places especially where the water is acidic. In this regard, concentrations of iron which exceeded the permissible value of $0.3 \mathrm{mg} / \mathrm{l}$ at a few boreholes in the district could result from the leaching of iron bearing minerals from the local geology due to the presence of slightly acidified groundwater. Water supplies from the boreholes which exceeded ZABS permissible value of $0.3 \mathrm{mg} / \mathrm{l}$ of iron may impart a metallic taste to drinking water.

Furthermore, about $49 \%$ of the borehole water samples recorded concentrations of sodium greater than the accepted limit of $1.5 \mathrm{mg} / \mathrm{l}$ set by the ZABS for drinking water. According to World Health Organisation (2003), most water supplies contain sodium levels less than 20mg/l although some countries can exceed $250 \mathrm{mg} / 1$. In this study, almost (about 95\%) all the water samples were found to be far less than $20 \mathrm{mg} / 1$ recommended by Environmental Protection Agency for drinking water.

Concentrations of sulphate in borehole water samples ranged from $0.0 \mathrm{mg} / \mathrm{l}$ to $18.76 \mathrm{mg} / \mathrm{l}$. About $37 \%$ of these samples recorded concentrations of sulphate greater than the permissible value of $1.0 \mathrm{mg} / 1$ set by the ZABS for drinking water. However, UNEP (1990) cited in (WHO, 2004) reports that typical concentrations of sulphate in fresh water are within $20 \mathrm{mg} / \mathrm{l}$ and can range from 0 to $230 \mathrm{mg} / \mathrm{l}$ in groundwater. In this study, concentrations of all borehole water samples were within the range of fresh water hence may not affect the health of the consumers. However, the presence of sulphate in drinking water can impart a noticeable taste and high concentrations may cause a laxative effect in unaccustomed consumers (WHO, 2008). In Mbala district, sulphate concentrations in all the water samples were less than $250 \mathrm{mg} / 1$ hence will likely cause minimal taste impairment.

\section{Microbiological Characteristics of the Borehole Water Samples}

The results for microbiological parameters of borehole water samples are presented in Table 5. It is observed that approximately $78 \%$ of borehole water samples complied with ZABS drinking water guideline values of $0 \mathrm{TC} / 100 \mathrm{ml}$ of water sample. The presence of total coliforms in a few water samples $(22 \%)$ indicates the potential of pathogenic organisms in water. The presence of total coliforms at a few boreholes in Mbala district could be attributed to the movement of microbial contaminants from waste dumps and pit latrines that are situated in close proximity to the affected boreholes. 
Assessment of Groundwater Quality in Rural Areas of Mbala.................NYIRENDA et al.

Table 3: Physical Parameters of Borehole Water Samples collected in Mbala District

\begin{tabular}{|c|c|c|c|c|c|c|}
\hline $\mathrm{BH}$ & Village Located & 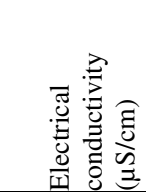 & 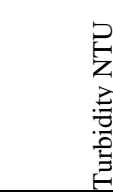 & 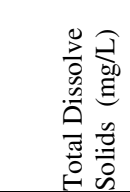 & 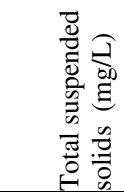 & \\
\hline & & 1500 & 5 & 800 & 100 & 250 \\
\hline 1 & Kombe School & 110 & 57 & 77 & 36 & 46 \\
\hline 2 & Senga North & 95.7 & 2 & 67 & 0.001 & 30 \\
\hline 3 & Chambezi Village & 74.29 & 3 & 52 & 0.001 & 18 \\
\hline 4 & Manyika Village & 132.86 & 2 & 93 & 0.001 & 66 \\
\hline 5 & Musatwe Village & 80 & 4 & 56 & 3 & 20 \\
\hline 6 & Iyanda B Village & 124 & 17 & 0.001 & 104 & 30 \\
\hline 7 & Iyanda Co school & 68.57 & 2 & 48 & 0.001 & 20 \\
\hline 8 & Kampandila Village & 111.43 & 56 & 78 & 31 & 16 \\
\hline 9 & Chitimbiti Village & 82.86 & 16 & 58 & 9 & 14 \\
\hline 10 & Ngelesani Village & 80 & 49 & 56 & 44 & 12 \\
\hline 11 & Mayanga Village & 51.43 & 11 & 36 & 9 & 10 \\
\hline 12 & Chiwindi Village & 56 & 8.5 & 42 & 7 & 18 \\
\hline 13 & Mwembe P School & 80 & 20 & 56 & 11 & 10 \\
\hline 14 & Chele Village & 181.43 & 16 & 127 & 110 & 60 \\
\hline 15 & Landula P School & 112 & 4 & 34 & 13 & 32 \\
\hline 16 & Chalunga/Kakozya & 88 & 3 & 102 & 26 & 22 \\
\hline 17 & Ntapita Vullage & 143 & 6 & 51 & 38 & 14 \\
\hline 18 & Chaya/ Ntondokoso & 102 & 2 & 27 & 42 & 32 \\
\hline 19 & Mulalo & 76 & 3 & 66 & 76 & 26 \\
\hline 20 & Kacheche Com. School & 67 & 4.2 & 33 & 38 & 0.001 \\
\hline 21 & Ngombezo Village & 221 & 8.8 & 111 & 107 & 0.001 \\
\hline 22 & Beni Village & 109 & 3.2 & 54 & 15 & 0.001 \\
\hline 23 & Saulo kela (chilyango & 242 & 12.2 & 121 & 125 & 0.001 \\
\hline 24 & Namatemba village & 191 & 4.9 & 95 & 32 & 0.001 \\
\hline 25 & Nsindano village & 52 & 6.3 & 26 & 46 & 0.001 \\
\hline 26 & Mulenga village & 43 & 6.3 & 21 & 28 & 0.001 \\
\hline 27 & Mwesela village & 67 & 5.1 & 23 & 20 & 0.001 \\
\hline 28 & Jeremia village & 73 & 10.3 & 37 & 105 & 0.001 \\
\hline 29 & Mpanga village & 203 & 12.8 & 102 & 128 & 0.001 \\
\hline 30 & Owen village & 147 & 3.9 & 74 & 14 & 0.001 \\
\hline 31 & Katambalile village & 159 & 11.2 & 80 & 108 & 0.001 \\
\hline 32 & Teya village & 121 & 10.7 & 61 & 102 & 0.001 \\
\hline 33 & Kasanga village & 47 & 2.9 & 23 & 17 & 0.001 \\
\hline 34 & Mwesela B village & 120 & 3.7 & 60 & 27 & 0.001 \\
\hline 35 & Kayawala Vlge & 156 & 2.7 & 78 & 17 & 0.001 \\
\hline 36 & Mwambala P. School & 120 & 2.1 & 60 & 18 & 0.001 \\
\hline 37 & Mbulauyo village & 144 & 7.2 & 72 & 33 & 0.001 \\
\hline 38 & Ng'ombe Village & 86 & 4 & 43 & 12 & 0.001 \\
\hline 39 & Seven Village & 222 & 4.2 & 111 & 45 & 0.001 \\
\hline 40 & Katuna Village & 76 & 4.5 & 38 & 13 & 0.001 \\
\hline 41 & Chisama Village & 68 & 3.5 & 34 & 17 & 0.001 \\
\hline 42 & Chikusela Village & 157 & 5 & 78 & 23 & 0.001 \\
\hline 43 & Maliko Village & 207 & 4.2 & 104 & 47 & 0.001 \\
\hline 44 & Sampatika Village & 69 & 4.2 & 35 & 10 & 0.001 \\
\hline 45 & Lwanda Village & 152 & 3.8 & 76 & 27 & 0.001 \\
\hline 46 & Sikalembe village & 148 & 4.2 & 74 & 37 & 0.001 \\
\hline 47 & Chilundumunsi vlg & 168 & 4 & 84 & 43 & 0.001 \\
\hline 48 & Tomo Village & 77 & 5 & 39 & 16 & 0.001 \\
\hline 49 & Siolwe Village & 149 & 4.7 & 75 & 27 & 0.001 \\
\hline 50 & Philimoni & 97 & 37.5 & 49 & 8 & 56 \\
\hline 51 & Susuntila & 159 & 26.2 & 80 & 6.9 & 92 \\
\hline 52 & Tomo & 244 & 11.3 & 122 & 4.6 & 142 \\
\hline 53 & Ali Chikoti & 150 & 3.84 & 76 & $<1.0$ & 82 \\
\hline 54 & Zukuza & 310 & 8.72 & 155 & $<1.0$ & 188 \\
\hline 55 & Nyenye & 334 & 48.6 & 167 & $<1.0$ & 330 \\
\hline 56 & Matelo & 46 & 171.6 & 24 & $<1.0$ & 58 \\
\hline 57 & Chilundumusi & 190 & 35 & 17 & 133 & 120 \\
\hline 58 & Mweembe Village & 511 & 358 & 358 & 266 & 100 \\
\hline 59 & Chela & 72.86 & 11 & 51 & 0 & 20 \\
\hline
\end{tabular}


Table 4: Chemical parameters of borehole water samples collected in Mbala District

\begin{tabular}{|c|c|c|c|c|c|c|c|c|c|c|c|c|c|}
\hline $\mathrm{BH}$ & Village Located & $\frac{\pi}{2}$ & 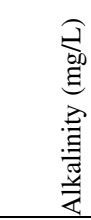 & 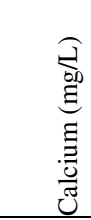 & 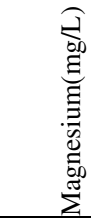 & 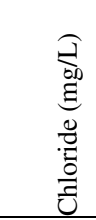 & 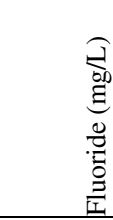 & 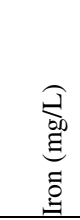 & 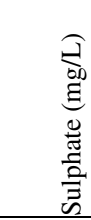 & 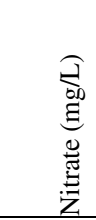 & 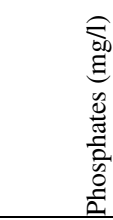 & 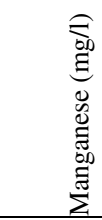 & 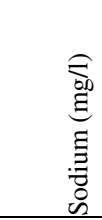 \\
\hline & & $6.5-8.0$ & 500 & 100 & 250 & ำ & 1.0 & 0.3 & 1.0 & 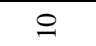 & 0.1 & $?$ & 1.5 \\
\hline 1 & Kombe School & 5.37 & 36 & 11.2 & 0.23 & 25 & $<0.01$ & 0.54 & 2 & 0.001 & $<0.01$ & 0.23 & 14.71 \\
\hline 2 & Senga North & 5.24 & 48 & 7.2 & 2.9 & 15 & $<0.01$ & 0.94 & 4 & 0.001 & $<0.01$ & 0.22 & 14.7 \\
\hline 3 & $\begin{array}{l}\text { Chambezi } \\
\text { Village }\end{array}$ & 5.14 & 24 & 3.2 & 2.43 & 17 & $<0.01$ & 0.47 & 1 & 0.001 & $<0.01$ & 0.22 & 18.58 \\
\hline 4 & $\begin{array}{l}\text { Manyika } \\
\text { Village }\end{array}$ & 5.44 & 86 & 1.6 & 15.07 & 20 & $<0.01$ & 0.42 & 4 & 0.001 & $<0.01$ & 0.05 & 19.23 \\
\hline 5 & $\begin{array}{l}\text { Musatwe } \\
\text { Village }\end{array}$ & 5.1 & 16 & 1.6 & 14.82 & 16 & $<0.01$ & 0.57 & 2 & 0.001 & $<0.01$ & 0.05 & 12.69 \\
\hline 6 & $\begin{array}{l}\text { Iyanda B } \\
\text { Village }\end{array}$ & 5.36 & 0.001 & 6.4 & 3.4 & 27 & $<0.01$ & 1.44 & 2 & 0.001 & $<0.01$ & 0.2 & 13.58 \\
\hline 7 & $\begin{array}{l}\text { Iyanda Co } \\
\text { school }\end{array}$ & 5.3 & 18 & 1.6 & 0.92 & 20 & $<0.01$ & 0.3 & 2 & 0.001 & $<0.01$ & 0.03 & 10.08 \\
\hline 8 & $\begin{array}{l}\text { Kampandila } \\
\text { Village }\end{array}$ & 6.1 & 30 & 4 & 1.46 & 43.99 & $<0.01$ & 0.14 & 8 & 0.001 & $<0.01$ & 0.15 & 12.72 \\
\hline 9 & $\begin{array}{l}\text { Chitimbiti } \\
\text { Village }\end{array}$ & 5.76 & 34 & 3.21 & 1.46 & 28.99 & $<0.01$ & 0.09 & 6 & 0.001 & $<0.01$ & 0.07 & 13.12 \\
\hline 10 & $\begin{array}{l}\text { Ngelesani } \\
\text { Village }\end{array}$ & 5.94 & 0.001 & 0.97 & 0.97 & 9.11 & $<0.01$ & 0.01 & 5 & 0.001 & $<0.01$ & 0.02 & 7.73 \\
\hline 11 & $\begin{array}{l}\text { Mayanga } \\
\text { Village }\end{array}$ & 6.77 & 0.001 & 2.81 & 0.73 & 11.36 & $<0.01$ & 0.01 & 1 & 0.001 & $<0.01$ & 0.06 & 8.19 \\
\hline 12 & $\begin{array}{l}\text { Chiwindi } \\
\text { Village }\end{array}$ & 6.1 & 22 & 1.72 & 0.88 & 17.23 & $<0.01$ & 0.02 & 4 & 0.001 & $<0.01$ & 0.04 & 10.2 \\
\hline 13 & $\begin{array}{l}\text { Mwembe P } \\
\text { School }\end{array}$ & 5.77 & 34 & 4 & 0.001 & 32.49 & $<0.01$ & 0.23 & 6 & 0.001 & $<0.01$ & 0.07 & 14.7 \\
\hline 14 & Chele Village & 6.75 & 12 & 18.44 & 3.4 & 19.49 & $<0.01$ & 0.09 & 8 & 0.001 & $<0.01$ & 0.12 & 18.33 \\
\hline 15 & $\begin{array}{l}\text { Landula P } \\
\text { School }\end{array}$ & 6.6 & 0.001 & 4.3 & 2.3 & 11.2 & $<0.01$ & 0.02 & 0.08 & 0.001 & $<0.01$ & 0.16 & 4.6 \\
\hline 16 & $\begin{array}{l}\text { Chalunga/Kako } \\
\text { zya }\end{array}$ & 6.8 & 0.001 & 1.8 & 4.6 & 5.7 & $<0.01$ & 0.03 & 0.01 & 0.001 & $<0.01$ & 0.11 & 6.7 \\
\hline 17 & Ntapita Vullage & 6 & 15 & 1.3 & 6.2 & 23 & $<0.01$ & 0.01 & 2 & 0.001 & $<0.01$ & 0.04 & 13.5 \\
\hline 18 & $\begin{array}{l}\text { Chaya/ } \\
\text { Ntondokoso }\end{array}$ & 5.9 & 9 & 2.4 & 4.5 & 19 & $<0.01$ & 0.02 & 3 & 0.001 & $<0.01$ & 0.03 & 9 \\
\hline 19 & Mulalo & 6.2 & 11 & 6.3 & 5.9 & 37 & $<0.01$ & 0.4 & 2 & 0.001 & $<0.01$ & 0.02 & 6.8 \\
\hline 20 & $\begin{array}{l}\text { Kacheche Com. } \\
\text { School }\end{array}$ & 6.3 & 0.001 & 0.001 & 0 & 4.7 & 0 & 0.02 & 0 & 0.03 & $<0.01$ & 0 & 0.001 \\
\hline 21 & $\begin{array}{l}\text { Ngombezo } \\
\text { Village }\end{array}$ & 6.8 & 0.001 & 0.001 & 0 & 1.56 & 0 & 0.06 & 0.01 & 0.03 & $<0.01$ & 0.01 & 0.001 \\
\hline 22 & Beni Village & 6.6 & 0.001 & 0.001 & 0 & 2.1 & 0 & 0.04 & 0 & 0.02 & $<0.01$ & 0 & 0.001 \\
\hline 23 & $\begin{array}{l}\text { Saulo kela } \\
\text { (chilyango }\end{array}$ & 6.9 & 0.001 & 0.001 & 0 & 3.72 & 0.01 & 0.08 & 0 & 0.03 & $<0.01$ & 0 & 0.001 \\
\hline 24 & $\begin{array}{l}\text { Namatemba } \\
\text { village }\end{array}$ & 6.5 & 0.001 & 0.001 & 0 & 2.82 & 0 & 0.01 & 0 & 0.01 & $<0.01$ & 0 & 0.001 \\
\hline 25 & $\begin{array}{l}\text { Nsindano } \\
\text { village }\end{array}$ & 5.8 & 0.001 & 0.001 & 0.001 & 1 & 0 & 0.04 & 0 & 0.03 & $<0.01$ & 0 & 0.001 \\
\hline 26 & Mulenga village & 5.8 & 0.001 & 0.001 & 0.001 & 2.2 & 0 & 0.02 & 0 & 0.01 & $<0.01$ & 0 & 0.001 \\
\hline 27 & Mwesela village & 6 & 0.001 & 0.001 & 0.001 & 3 & 0 & 0.04 & 0 & 0 & $<0.01$ & 0 & 0.001 \\
\hline 28 & Jeremia village & 6.2 & 0.001 & 0.001 & 0.001 & 3.5 & 0 & 0.02 & 0 & 0.01 & $<0.01$ & 0 & 0.001 \\
\hline 29 & Mpanga village & 6.7 & 0.001 & 0.001 & 0.001 & 4.8 & 0 & 0.07 & 0 & 0.02 & $<0.01$ & 0.01 & 0.001 \\
\hline 30 & Owen village & 6.5 & 0.001 & 0.001 & 0.001 & 3.8 & 0 & 0 & 0 & 0.01 & $<0.01$ & 0 & 0.001 \\
\hline 31 & $\begin{array}{l}\text { Katambalile } \\
\text { village }\end{array}$ & 6.5 & 0.001 & 0.001 & 0.001 & 4.5 & 0 & 0.13 & 0 & 0.01 & $<0.01$ & 0.01 & 0.001 \\
\hline 32 & Teya village & 6.7 & 0.001 & 0.001 & 0.001 & 2.5 & 0 & 0.04 & 0 & 0.02 & $<0.01$ & 0 & 0.001 \\
\hline 33 & Kasanga village & 6.5 & 0.001 & 0.001 & 0.001 & 3.2 & 0 & 0.01 & 0 & 0 & $<0.01$ & 0 & 0.001 \\
\hline 34 & $\begin{array}{l}\text { Mwesela B } \\
\text { village }\end{array}$ & 6.5 & 0.001 & 0.001 & 0.001 & 3.75 & 0 & 0 & 0 & 0.03 & $<0.01$ & 0 & 0.001 \\
\hline 35 & Kayawala Vlge & 6.7 & 0.001 & 0.001 & 0.001 & 5.2 & 0 & 0 & 0 & 0.01 & $<0.01$ & 0 & 0.001 \\
\hline 36 & Mwambala P. & 6.5 & 0.001 & 0.001 & 0.001 & 3.2 & 0 & 0.01 & 0 & 0.001 & $<0.01$ & 0 & 0.001 \\
\hline
\end{tabular}




\begin{tabular}{|c|c|c|c|c|c|c|c|c|c|c|c|c|c|}
\hline 37 & $\begin{array}{l}\text { School } \\
\text { Mbulauyo } \\
\text { village }\end{array}$ & 6.9 & 0 & 0.001 & 0.001 & 17 & 0 & 0.09 & 0 & 0.04 & $<0.01$ & 0.01 & 0.001 \\
\hline 38 & $\begin{array}{l}\text { Ng'ombe } \\
\text { Village }\end{array}$ & 6.1 & 0 & 0.001 & 0.001 & 6 & 0 & 0.04 & 0 & 0 & $<0.01$ & 0 & 0.001 \\
\hline 39 & Seven Village & 6.6 & 0 & 0.001 & 0.001 & 7.1 & 0 & 0.05 & 0.03 & 0.04 & $<0.01$ & 0 & 0.001 \\
\hline 40 & Katuna Village & 6.5 & 0 & 0.001 & 0.001 & 8 & 0 & 0.03 & 0 & 0.02 & $<0.01$ & 0 & 0.001 \\
\hline 41 & $\begin{array}{l}\text { Chisama } \\
\text { Village }\end{array}$ & 6.6 & 0 & 0.001 & 0.001 & 7.5 & 0 & 0.04 & 0 & 0.02 & $<0.01$ & 0 & 0.001 \\
\hline 42 & $\begin{array}{l}\text { Chikusela } \\
\text { Village }\end{array}$ & 6.5 & 0 & 0.001 & 0.001 & 9.2 & 0 & 0.07 & 0 & 0.06 & $<0.01$ & 0 & 0.001 \\
\hline 43 & Maliko Village & 6.6 & 0 & 0.001 & 0.001 & 10.2 & 0 & 0.09 & 0 & 0.04 & $<0.01$ & 0.01 & 0.001 \\
\hline 44 & $\begin{array}{l}\text { Sampatika } \\
\text { Village }\end{array}$ & 6 & 0 & 0.001 & 0.001 & 3 & 0 & 0.02 & 0 & 0 & $<0.01$ & 0 & 0.001 \\
\hline 45 & Lwanda Village & 6.2 & 0.001 & 0.001 & 0.001 & 5.5 & 0 & 0.03 & 0 & 0.08 & $<0.01$ & 0 & 0.001 \\
\hline 46 & $\begin{array}{l}\text { Sikalembe } \\
\text { village }\end{array}$ & 6.6 & 0.001 & 0.001 & 0.001 & 15 & 0 & 0.07 & 0 & 0.06 & $<0.01$ & 0 & 0.001 \\
\hline 47 & $\begin{array}{l}\text { Chilundumunsi } \\
\text { vlg }\end{array}$ & 6.4 & 0.001 & 0.001 & 0.001 & 18 & 0 & 0.03 & 0 & 0.03 & $<0.01$ & 0 & 0.001 \\
\hline 48 & Tomo Village & 5.9 & 0.001 & 0.001 & 0.001 & 10 & 0 & 0.05 & 0 & 0.04 & $<0.01$ & 0 & 0.001 \\
\hline 49 & Siolwe Village & 6.4 & 0.001 & 0.001 & 0.001 & 14 & 0 & 0.04 & 0 & 0.01 & $<0.01$ & 0 & 0.001 \\
\hline 50 & Philimoni & 6.56 & 50 & 15.2 & 4.32 & 15 & 0.09 & 2.84 & 1.56 & $<0.01$ & $<0.01$ & 0.02 & 9.02 \\
\hline 51 & Susuntila & 6.66 & 88 & 18.4 & 11.04 & 17 & 0.11 & 1.96 & 18.76 & 3.93 & $<0.01$ & $<0.01$ & 12.22 \\
\hline 52 & Tomo & 6.62 & 140 & 40 & 10.8 & 32 & 0.14 & 0.88 & 1.59 & $<0.01$ & $<0.01$ & $<0.01$ & 22.04 \\
\hline 53 & Ali Chikoti & 6.94 & 80 & 21.6 & 6.72 & 17 & 0.13 & $\begin{array}{l}<0.0 \\
1\end{array}$ & $<0.01$ & $<0.01$ & $<0.01$ & $<0.01$ & 13.11 \\
\hline 54 & Zukuza & 6.94 & 182 & 41.6 & 20.16 & 25 & 0.16 & 0.8 & $<0.01$ & $<0.01$ & $<0.01$ & $<0.01$ & 36.11 \\
\hline 55 & Nyenye & 6.88 & 312 & 36.8 & 57.12 & 36 & 0.16 & 3.13 & 3.53 & $<0.01$ & $<0.01$ & 0.04 & 49.9 \\
\hline 56 & Matelo & 5.84 & 50 & 5.6 & 10.56 & 5.65 & 0.09 & $\begin{array}{l}10.2 \\
2\end{array}$ & $<0.01$ & $<0.01$ & $<0.01$ & 0.05 & 15.01 \\
\hline 57 & Chilundumusi & 6.73 & 160 & 35.3 & 7.8 & 20 & 0.01 & 0.01 & 2 & 0 & 0.3 & 0.012 & 2.13 \\
\hline 58 & $\begin{array}{l}\text { Mweembe } \\
\text { Village }\end{array}$ & 6.98 & 40 & 38.5 & 0.97 & 20 & 0.01 & 0.18 & 18 & 0 & 0.3 & 0.012 & 7.45 \\
\hline 59 & Chela & 6.49 & 150 & 4.8 & 1.9 & 20 & 0.01 & 0.04 & 3 & 0 & 0.6 & 0.02 & 5.36 \\
\hline
\end{tabular}


Table 5: Microbiological parameters of borehole water samples collected in Mbala District

\begin{tabular}{|c|c|c|c|c|}
\hline $\mathrm{BH}$ & Village Located & \multicolumn{2}{|c|}{ 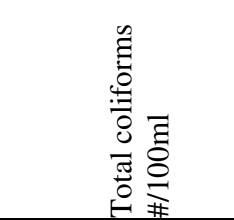 } & 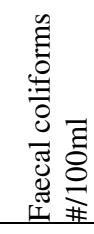 \\
\hline & & $\mathbf{0}$ & $\mathbf{0}$ & \\
\hline 1 & Kombe School & 0 & 0 & \\
\hline 2 & Senga North & 0 & 0 & \\
\hline 3 & Chambezi Village & 0 & 0 & \\
\hline 4 & Manyika Village & 0 & 0 & \\
\hline 5 & Musatwe Village & 0 & 0 & \\
\hline 6 & Iyanda B Village & 0 & 0 & \\
\hline 7 & Iyanda Co school & 0 & 0 & \\
\hline 8 & Kampandila Village & 0 & 0 & \\
\hline 9 & Chitimbiti Village & 0 & 0 & \\
\hline 10 & Ngelesani Village & 0 & 0 & \\
\hline 11 & Mayanga Village & 0 & 0 & \\
\hline 12 & Chiwindi Village & 0 & 0 & \\
\hline 13 & Mwembe P School & 0 & 0 & \\
\hline 14 & Chele Village & 0 & 0 & \\
\hline 15 & Landula P School & 0 & 0 & \\
\hline 16 & Chalunga/Kakozya & 0 & 0 & \\
\hline 17 & Ntapita Vullage & 0 & 0 & \\
\hline 18 & Chaya/ Ntondokoso & 0 & 0 & \\
\hline 19 & Mulalo & 0 & 0 & \\
\hline 20 & Kacheche Com. School & 0 & 0 & \\
\hline 21 & Ngombezo Village & 0 & 0 & \\
\hline 22 & Beni Village & 0 & 0 & \\
\hline 23 & Saulo kela (chilyango & 0 & 0 & \\
\hline 24 & Namatemba village & 6 & 0 & \\
\hline 25 & Nsindano village & 0 & 0 & \\
\hline 26 & Mulenga village & 0 & 0 & \\
\hline 27 & Mwesela village & 0 & 0 & \\
\hline 28 & Jeremia village & 0 & 0 & \\
\hline 29 & Mpanga village & 0 & 0 & \\
\hline 30 & Owen village & 0 & 0 & \\
\hline 31 & Katambalile village & 28 & 0 & \\
\hline 32 & Teya village & 0 & 0 & \\
\hline 33 & Kasanga village & 7 & 0 & \\
\hline 34 & Mwesela B village & 8 & 0 & \\
\hline 35 & Kayawala Vlge & 20 & 0 & \\
\hline 36 & Mwambala P. School & 0 & 0 & \\
\hline 37 & Mbulauyo village & 0 & 0 & \\
\hline 38 & Ng'ombe Village & 7 & 0 & \\
\hline 39 & Seven Village & 8 & 0 & \\
\hline 40 & Katuna Village & 0 & 0 & \\
\hline 41 & Chisama Village & 0 & 0 & \\
\hline 42 & Chikusela Village & 3 & 0 & \\
\hline 43 & Maliko Village & 0 & 0 & \\
\hline 44 & Sampatika Village & 16 & 0 & \\
\hline 45 & Lwanda Village & 0 & 0 & \\
\hline 46 & Sikalembe village & 3 & 0 & \\
\hline 47 & Chilundumunsi vlg & 0 & 0 & \\
\hline 48 & Tomo Village & 8 & 0 & \\
\hline 49 & Siolwe Village & 1 & 0 & \\
\hline 50 & Philimoni & 0 & 0 & \\
\hline 51 & Susuntila & 0 & 0 & \\
\hline 52 & Tomo & 0 & 0 & \\
\hline
\end{tabular}




\begin{tabular}{llll}
\hline 53 & Ali Chikoti & 0 & 0 \\
54 & Zukuza & 0 & 0 \\
55 & Nyenye & 0 & 0 \\
56 & Matelo & 0 & 0 \\
57 & Chilundumusi & 0 & 0 \\
58 & Mweembe Village & 17 & 68 \\
59 & Chela & 0 & 0 \\
\hline
\end{tabular}

\section{Conclusion}

Results from this study generally indicate that most water parameters complied with the Zambian Bureau of Standards (ZABS) drinking water guideline values. A few chemical parameters which include $\mathrm{pH}, \mathrm{Na}, \mathrm{Fe}$, $\mathrm{Mn}$ and sulphate did not meet ZABS guideline values for drinking water at a few boreholes although water supplies from these boreholes will not affect the health of the consumers. Physical parameters which include electrical conductivity (EC) and hardness complied with ZABS drinking water guideline values except for total suspended solids (TSS) and turbidity. TSS and turbidity levels from a few borehole water samples exceeded ZABS permissible values for drinking water. In contrast, significantly high turbidity levels were recorded in a few water samples in Mbala district thus posing a significant threat to the health of the consumers.

\section{Acknowledgement}

I would like to acknowledge World Vision Zambia for its valuable assistance on this paper

\section{References}

American Water Works Association (1995). Standard Methods for the Examination of Water and Wastewater, $19^{\text {th }}$ Edition.

British Geological Survey (2001). Water Quality: Zambia

Bury T., Saunders D., Visscher J.T. (1998). An assessment of promising approaches in drinking water supply related water resources management

GEOHIVE (2015). Zambia (Available on http://www.geohive.com/cntry/zam bia.aspx, Accessed on 01/06/2015)

Geological Survey of Sweden (2014). Environmental Impacts of Mining in Zambia

Giovanoli R., Schnoor J.L., Sigg L., Stumm W., Zobrist J. (1988). Chemical Weathering of Crystalline Rocks in the Catchment Area of Acidic Ticino Lakes, Switzerland

International Groundwater Resources Assessment Centre (2013). Groundwater Monitoring in SADC Region

International Water Management Institute, 2012.Groundwater Availability and Use in Sub-Sahara Africa: A Review of 15 Countries

JICA (1995). The Study of the National Water Resources Master Plan in the Republic of Zambia

MacDonald and Partners (1990). Hydrogeological map of Zambia. 1:1,500,000 scale. Philip Print Ltd, London.

Norrgren, L., Pettersson, U., Orn, S. and Bergqvist, P.A. (2000). Environmental monitoring of the Kafue River, located in the Copperbelt, Zambia

SRK (2002). Compilation of the Hydrogeological Map Atlas for SADC Region

UNEP/WHO (1996). Water Quality Monitoring-A Practical Guide to 
Assessment of Groundwater Quality in Rural Areas of Mbala................NYIRENDA et al.

the Design and Implementation of Freshwater Quality Studies and Monitoring Programmes

University of Gothenburg (2010). Zambia Environmental and Climate Change Policy Brief

UNICEF (2002). Report on the Rapid Assessment of Unsupported PMTCT Pilot Programme in Zambia

United States Environmental Protection Agency (2015). Quality of Groundwater. (Accessed on
21/06/2015, Available on uhttp://pubs.usgs.gov/gip/gw/qualit y.html)

Water Research Australia. (2013). Fact Sheet: Manganese in Drinkingwater

World Health Organisation (2003). Sodium in Drinking-water

World Health Organisation (2004). Sulphate in Drinking-water

World Health Organisation (2008). Guideline for Drinking Water Quality 